\title{
STUDI KUAT TEKAN BETON DENGAN AGREGAT KASAR DARI BATU KAPUR
}

\author{
Hartono \\ Program Diploma III Teknik Sipil \\ Fakultas Teknik Universitas Diponegoro
}

\begin{abstract}
Hartono, in this paper explain that to obtain the allowed characteristic compressive strength of concrete from a concrete construction is quite difficult, because it is influenced by the mix of materials used for the manufacture of the construction, in which the require material of the concrete mix had to be in accordance with Reinforced Concrete Indonesia Rule Year 1991. The main factor of mix material that affect permitted the compressive strength of concrete is aggregate characteristics, namely the coarse aggregate or crushed stone. Therefore this study is intended to determine the compressive strength of concrete with the characteristics of coarse aggregate material of crushed stone that comes from limestone. This research use Gresik PC mixture concrete, muntilan sand, and kricak of limestone. To determine concrete compressive characteristics strength of concrete, concrete specimen as many as 20 pieces, with mixed-use PC weight ratio of $1: 2$ Ps : 3, cube molded kricak with the size of $15 \mathrm{~cm} X 15 \mathrm{~cm} X 15 \mathrm{~cm}$ was made. From these results, it can be obtained that concrete compressive characteristic strength $\sigma^{1} \mathrm{bk}=215.41 \mathrm{~kg} / \mathrm{cm}^{2}$.
\end{abstract}

Keyword: Concrete construction

\section{PENDAHULUAN}

Beton yang digunakan sebagai struktur dalam konstruksi teknik sipil, dapat dimanfaatkan untuk banyak hal. Dalam teknik sipil, struktur beton digunakan untuk bangunan pondasi, kolom, balok, pelat atau pelat cangkang. Dalam teknik sipil hidro, beton digunakan untuk bangunan air seperti bending, bendungan, saluran dan drainase perkotaan. Beton juga digunakan untuk teknik sipil tranportasi untuk pekerjaan rigid pavemen (lapis keras permukaan yang kaku).

Jadi beton hampir digunakan dalam semua aspek ilmu teknik sipil, artinya semua struktur dalam teknik sipil akan menggunakan beton, minimal dalam pekerjaan pondasi (Tri Mulyono, 2005).

Beton dalam konstruksi teknik sipil didifinisikan sebagai batu buatan yang dicetak pada suatu wadah atau cetakan dalam keadaan cair kental, yang kemudian mampu mengeras secara baik.

Beton terdiri dari agregat halus, agregat kasar dan suatu bahan pengikat. Bahan pengikat yang lazim digunakan pada umumnya adsalah bahan pengikat yang bersifat hidrolik dalam arti akan mengikat dan mengeras secara baik kalau dicampur dengan air.

Bahan pengikat yang dipakai umumnya adalah jenis semen Portland atau disebut juga Portland Cement (PC). Agregat kasar umumnya adalah dipakai krikel atau batu pecah kecil atau kricak dan sebagai agregat halus lazim digunakan pasir.

Beton konvensional adalah suatu batuan buatan yang dicetak pada suatu cetakan, yang terdiri dari campuran semen Portland, agregat kasar atau batu pecah, agregat halus pasir dengan perbandingan tertentu ditambah air secukupnya dan dapat mengeras dengan sendirinya.

Masalah yang dihadapi para perencana adalah bagaimana merencanakan komposisi dari bahan-bahan penyusun beton tersebut agar dapat memenuhi spesifikasi teknik yang ditentukan.

Parameter -parameter yang paling mempengaruhi kekuatan tekan beton adalah: a). kualitas semen, b).proporsi semen terhadap campuran, c).kekuatan dan kebersihan agregat, d).interaksi atau adesi antara pasta semen dengan agregat, e). pencampuran yang cukup dari bahanbahan pembentuk beton, f). penempatan yang benar, penyelesaian dan pemadatan beton, $\mathrm{g}$ ). perawatan beton dan h). kandungan klorida tidak melebihi $0,15 \%$ dalam beton yang diekpos dan $1 \%$ bagi beton yang tidak diekpos (Ahmad Antono, 1989).

\section{TINJAUAN PUSTAKA. Definisi Beton.}

Beton adalah campuran dari agregat, Portland cement dan air dengan komposisi tertentu yang kemudian dicetak dalam suatu acuan sampai mengeras dengan baik. Agregat dalam campuran ini terdiri dua macam yaitu agregat halus yang berupa pasir dan agregat kasar yang berupa kerikil atau batu pecah (kricak).

Beton merupakan fungsi dari bahan penyusunananya yang terdiri dari bahan semen hidrolik (Portland cement), agregat kasar, agregat halus, air dan bahan tambahan (admixture atau additive)(Ahmad Antono, 1989).

Portland cement disini berperan sebagai bahan pengikat hydrolik, yang artinya akan mengikat dan mengeras secara baik kalau di campur air. 
Sesuai pengertian beton diatas, maksud komposisi tertentu adalah perbandingan campurannya. Artinya tidak dapat sembarangan menentukan perbandingan campuran untuk beton itu. Dengan kata lain komposisi atau perbandingan campuran disesuaikan dengan maksud penggunaan beton.

Setelah terjadi pengerasan, beton dalam suatu konstruksi hanya menahan tegangan tekan saja. Maka bagian yang menahan tarik perlu diperkuat dengan bahan lain dari baja sebagai tulangan, karena kekuatan tarik dari beton sangat kecil.

\section{Bahan - Bahan Untuk Membuat Beton Portland Cement.}

Portland cement merupakan komponen utama beton yang berfungsi sebagai bahan pengikat anorganik secra umum mempunyai sifat utama sebagai pengikat dan pengeras secara hydrolik. Portland cement berupa bubukan halus dengan diameter butir sekitar $0,50 \mathrm{~mm}$, yang pada hakekatnya merupakan hablur-hablur senyawa kompleks. Bahan baku semen terdiri dari $\mathrm{CaO}(60$ $-70 \%), \mathrm{S}_{1} \mathrm{O}_{2}(19-24 \%), \mathrm{Al}_{2} \mathrm{O}_{3}(4-8 \%)$ dan $\mathrm{Fe}_{2}(2-6 \%)$.

Bila butir-butir semen berhubungan dengan air, maka butir-butir tersebut akan terpecah secara sempurnya, sehingga terjadi hydrasi dan terbentuklah suatu adonan jenang yang dapat disebut perekat mineral. Adonan semen ini bersama agregat kasar dan halus, diaduk secara sempurna untuk kemudian dicorkan sebagai mortel beton.

\section{Agregat}

Agregat adalah butiran mineral yang apabila dicampur dengan Portland cement akan menghasilkan beton. Ditinjau dari asalnya agregat ada dua macam yaitu agregat alam dan buatan. Agregat alam dilihat dari diameter butiran (ukuran) ada dua jenis yaitu agregat halus (pasir) dan agregat kasar (krikil dan batu pecah).

Agregat merupakan bahan pengisi yang netral dalam membuat beton dan prosentasinya sekitar $70-75 \%$ dari masa beton. Selain itu agregat berfungsi untuk menghemat penggunaan Portland cement . Jadi semakin banyak pemakaian agregat, semakin sedikit pemakaian Portland cement. Namun hal ini tetap ada batasnya, asalkan pasta semen cukup untuk melekatkan butir, pengisi rongga-rongga halus dan sifat dapat dikerjakan.

Dengan agregat yang baik akan dihasilkan pula beton yang lebih padat. Kekuatannya harus melebihi kekuatan pasta semen yang telah mengeras.

Pemakaian agregat dapat pula berfungsi untuk mengurangi penyusutan pada proses pengerasan beton. Jadi semakin banyak agregat di dalam beton semakin berkurang susut pengerasan beton.
Agregat halus di dalam pembuatan beton adalah pasir. Pasir merupakan batuan halus yang berukuran $0,14-15 \mathrm{~mm}$. Agregat ini diperoleh dari pasir alam dan pasir yang dibuat dari batuan yang ditumbuk (dihaluskan). Sesuai dengan yang disyaratkan pada PBI 1991.

Agregat kasar sebagai bahan campuran beton dapat berupa kerikil atau batu pecah. Kerikil merupakan batuan alami yang biasanya mempunyai permukaan agak licin. Sedangkan batu pecah (kricak) didapatkan dari memecah batu-batu baik dengan manual ataupun dengan mesin pemecah batu. Dari hasil pemecahan ini, biasanya kericak mempunyai permukaan yang agak kasar dan tajam. Hal ini menimbulkan gesekan yang besar dan memerlukan mobilitas yang lebih tinggi dibandingkan dengan kerikil dalam proses pembuatan beton. Namun dalam hal ini kricak justru menjamin ikatan yang lebih kokoh dengan pasta semen.

Relevansinya dengan masalah ini adalah dengan menggunakan agegat kasar dari batu kapur diharapkan dapat digunakan sebagai agregat kasar untuk pembuatan beton konvensional, yaitu untuk pembuatan rumah tinggal, seperti sloof, kolom dan ringbalk karena konstruksi tersebut termasuk beton non struktur.

\section{Air}

Peranan air dalam proses pembuatan beton cukup penting. Air tersebut perpengaruh terhadap pembuatan pasta semen, yaitu sidapat dikerjakan, adukan beton, kekuatan susut dan keawetanya. Selain itu air berpengaruh pada kelangsungan reaksi dari Portland cement sehingga dihasilkan kekerasan dan kekuatan sesudah beberapa waktu. Setelah pengecoran, air juga berpengaruh pada perawatan dalam pengerasan beton guna menjamin pengerasan sempurna.

Penggunaan air haruslah sedemikian rupa sehingga tidak terlalu sedikit atau terlalu banyak, yang disesuaikan dengan pembuatan beton. Air yang terlalu sedikit proses pembuatanya tidak akan baik dan sukar untuk dikerjakan.

\section{Presentase Komposisi Beton.}

Pada beton yang baik, setiap butir agregat seluruhnya terbungkus dengan mortar. Demikian pula halnya dengan ruang antar agregat, harus terisi oleh mortar. Jadi kualitas pasta atau mortar menentukan kualitas beton. Semen adalah unsure kunci dalam beton, meskipun jumlahnya hanya 7 $15 \%$ dari campuran lihat gambar 1.

Beton dengan jumlah semen yang sedikit (sampai $7 \%$ ) disebut beton kurus (lean concrete), sedang beton dengan jumlah semen yang banyak (sampai $15 \%$ ) disebut beton gemuk (rich concrete).(Paul Nugraha,Antoni, 2007).

Sifat masing-masing bahan juga berbeda dalam hal perilaku beton segar maupun pada saat 
sudah mengeras, selain factor biaya yang perlu diperhatikan. Di lain pihak, secxara volumetric beton diisi oleh agregat sebayak $61-76 \%$. Jadi agregat juga mempunyai peran yang sama pentingnya sebagai material pengisi beton.

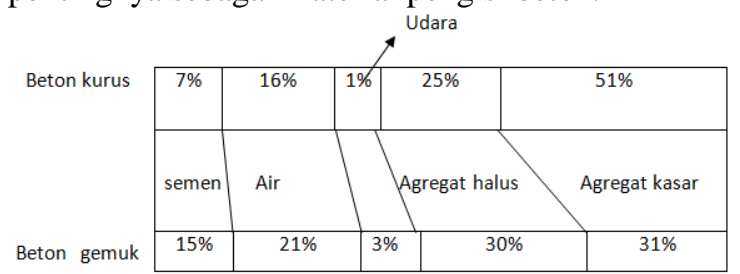

Sumber : Paul Nugraha, Antoni.

Gambar 1. Koposisi Campuran Beton

Dari gambar komposisi campuran beton dapat dilihat bahwa agregat kasar mempunyai volume yang cukup besar, ini akan dapat mempengaruhi kualitas beton itu sendiri.

\section{Batu Kapur}

Batu kapur ( limestone) $\left(\mathrm{CaCO}_{3}\right)$ adalah sebuah batuan sedimen terdiri dari mineral calcite(kalsium carbonate). Sumber utama dari calcite ini adalah organism laut. Organisme ini mengeluarkan shell yang keluar ke air dan terdeposit di lantai samudra sebagai pelagic ooze

Batu Kapur dapat terjadi dengan beberapa cara yaitu secara organik secara mekanik atau secara kimia sebagian batu kapur dialam terjadi secara organik. Jenis ini berasal dari pengembangan cangkang atau rumah kerang dan siput. Untuk batu kapur yang terjadi secara mekanik sebetulnya bahannya tidak jauh beda dengan batu kapur secara organik yang membedakannya adalah terjadinya perombakan dari bahan batu kapur tersebut kemudian terbawa oleh arus dan biasanya diendapkan tidak jauh dari tempat semula. Sedangkan yang terjadi secara kimia jenis batu kapur yang terjadi dalam kondisi iklim dan suasana lingkungan tertentu dalam air laut ataupun air tawar.

Secara kimia batugamping terdiri atas Kalsium karbonat $\left(\mathrm{CaCO}_{3}\right)$. Dialam tidak jarang pula dijumpai batugamping magnesium. Kadar magnesium yang tinggi mengubah batugamping dolomitan dengan komposisi kimia $\mathrm{CaCO}_{3} \mathrm{MgCO}_{3}$. Adapun sifat dari batu gamping adalah sebagai berikut :

- Warna

- Kilap

- Goresan

Putih, putih kecoklatan, dan putih keabuan

- Bidang belahan : Tidak teratur

- Pecahan : Uneven

- Kekerasan : 2,7-3,4 skala mohs

- Berat Jenis : 2,387 Ton $/ \mathrm{m}^{3}$

- Tenacity

\section{Kekuatan Agregat}

Kekuatan beton tidak lebih tinggi dari kekuatan agregat, oleh karena itu sepanjang kekuatan tekan agregat lebih tinggi dari beton yang akan dibuat maka agregat tersebut masih cukup aman digunakan sebagai cam puran beton.(Tri Mulyono, 2005)

\section{METODOLOGI PENELITIAN}

Tahapan Penelitian :

Penelitian ini dibagi menjadi 2 tahap yaitu :

- Penelitian tentang agregat kasar(kricak) dari pecahan batu kapur.

- Penelitian tentang beton dengan menggunakan campuran agregat kasar (kricak) dari pecahan batu kapur.

\section{Populasi dan Sampel.}

Sebagai populasi adalah agregat kasar(kricak) dari pecahan batu kapur yang diambil secara randem sampling dari daerah Grobogan Purwodadi dan di daerah Blora, sampel ini kemudian diuji secara gradasinya dan fisik.

Membuat sampel beton dicetak sebanyak 20 buah, berupa kubus beton, berukuran 15 x 15 x 15 $\mathrm{cm}$. Untuk membuat kubus beton ini digunakan perbandingan campuran berat 1 PC : 2 PS : 3 kerikil, dengan factor air semen 0,55, sedangkan PCnya menggunakan PC Gresik, air dari PAM.

\section{Teknik Pengumpulan Data dan Analisa.}

Metode pengujian agregat kasar dilakukan dengan 3 cara yaitu : Kandungan lumpur, Kekuatan tekan karakteristik beton.

Untuk mencari kuat tekan beton karakteristik, sampel beton sebanyak 20 buah kubus beton kemudian dites dengan mesin tekan beton. Hasil pengujian kemudian dianalisa dengan rumus (PBI 1991)

$$
\begin{aligned}
\sigma_{b m} & =\frac{\sum_{1}^{n} \sigma b^{1}}{n} \\
\mathrm{~S} & =\sqrt{\frac{\sum_{1}^{n}\left(\sigma b^{1}-\sigma_{b m}\right)^{2}}{n-1}} \\
\sigma_{b k} & =\sigma_{b m}{ }^{1}-1,64 \mathrm{~S}
\end{aligned}
$$

Keterangan:

$\sigma_{b} \quad=$ kuat tekan beton yang didapat dari masing-masing kubus beton.

$\sigma_{b m}=$ kuat tekan beton rata- rata.

$\mathrm{S} \quad=$ simpang baku

$\mathrm{n} \quad=$ jumlah sampel

$\sigma_{b k}=$ kuat beton karakteristik $\left(\mathrm{kg} / \mathrm{cm}^{2}\right)$

\section{PELAKSANAAN PENELITIAN \\ Bahan}

Bahan - bahan yang dipakai dalam

penelitian ini ialah sebagai berikut :

- Semen Portland

Semen portland yang dipakai pada penelitian ini ialah semen Portlan Gresik. Kantong 
semen dalam keadaan bagus, tertutup rapat dan tidak ada bagian yang menggumpal. Hasil pemeriksaan berat satuan menunjukkan bahwa berat satuan semen Gresik yaitu sebasar 1,28

- Pasir

Pasir yang dipakai ialah pasai dari Muntilan. Pasir ini mempunyai berat satun 2,45 dari lima kali pemeriksaan, yang setiap kalinya dilakukan atas 500 gr pasir, diperoleh modulus halus butir antara 3,5 dan 3,7

- Kricak.

Kricak yang dipakai berasal dari pecahan batu kapur. Kerikil ini mempunyai berat satuan 1,45. Dari lima kali pemeriksaan, yang setiap kalinya dilakukan atas $10 \mathrm{~kg}$ kerikil.

- Air

Air yang dipakai diperoleh dari PDAM

Semarang

\section{Analisa Hasil Penelitian}

Data yang didapat dari masing - masing pengujian kubus beton, yaitu beton yang menggunakan agregat kasar batu pecah dari batu kapur kemudian dihitung kekuatan tekan karakteristik betonnya.

Dari perolehan nilai kuat tekan beton karakteristik untuk masing - masing beton yang menggunakan kricak batu kapur, akan didapat nilai banding yang diharapkan.

\section{Hasil Penelitian Dan Pembahasan}

Sebelum bahan - bahan campuran untuk pembuatan benda uji yang berupa kubus beton, terlebih dahulu diadakan pemeriksaan bahan bahan untuk campuran, seperti pasir, mengenai kandungan air dalam pasir alami, ini pengaruhnya pada faktor air semen, kandungan lumpur pada pasir, hasil dari pemeriksaan kandungan lumpur sebesar : 0,0094\%, berarti pasir muntilan memenuhi syarat untuk pembuatan beton, karena dalam PBI 1991, kandungan lumpur maksimum adalah 5\%, mengenai pemeriksaan berat satuan pasir adalah : 2,15 . Air yang digunakan adalah air dari PAM, jadi airnya sudah memenuhi syarat untuk pembuatan beton. Sesudah mengadakan pemeriksaan bahanbahan, tahap selanjutnya adalah pembuatan benda uji kubus beton. Bahan - bahan campuran beton, dicampur menggunakan perbandingan berat pada setiap kali membuat adukan. Berdasarkan hal tersebut dan persyaratan lain, misalnya gradasi butiran campuran kerikil dan pasir dari "Road Mate", faktor air semen dan nilai "Slump" minimum $50 \mathrm{~mm}$, maka dapat dihitung kuat tekan karakteristik beton, yaitu menggunakan sebagai berikut: Perhitungan kuat tekan karkarakteristik beton, dengan campuran Agregat kasar dari pecahan batu kapur.

$$
\sigma^{1} \mathrm{bm}=\frac{\sum_{1}^{\mathrm{N}} \sigma_{\mathrm{b}^{1}}}{\mathrm{~N}}=\frac{4789,91}{20}=239,50 \mathrm{~kg} / \mathrm{cm}^{2}
$$

$$
\begin{aligned}
& \mathrm{s}=\sqrt{\frac{\sum_{1}^{\mathrm{N}}\left(\sigma^{1} \mathrm{~b}-\sigma^{1} \mathrm{bm}\right)^{2}}{\mathrm{~N}-1}}=\sqrt{\frac{4098,84}{19}=215,73} \\
&= 14,69 \mathrm{~kg} / \mathrm{cm}^{2} \\
& \sigma^{1} \mathrm{bk}=\sigma_{\mathrm{bm}}^{1}-1,64 . \mathrm{s} \\
&=239,50 \mathrm{~kg} / \mathrm{cm}^{2}-1,6.14,69 \mathrm{~kg} / \mathrm{cm}^{2} \\
&= 215,41 \mathrm{~kg} / \mathrm{cm}^{2}
\end{aligned}
$$

Dari hasil penelitian ini dapat diketahui bahwa kekuatan tekan karakteristik beton dengan menggunakan kricak dari batu kapur, dengan perbandingan campuran 1 PC : 2 pasir : 3 kerikil, adalah $\sigma^{1} \mathrm{bk}=215,41 \mathrm{~kg} / \mathrm{cm}^{2}$, berarti termasuk beton mutu K.175 dan termasuk klas II. Dengan demikian kricak dari batu kapur adalah cocok untuk pembuatan rumah tinggal.

\section{KESIMPULAN DAN SARAN Kesimpulan}

kesimpulan:

Dari hasil penelitian dapat diambil

- Agregat halus atau pasir dari Muntilan yang digunakan untuk pembuatan beton adalah cukup baik dan memenuhi syarat seperti yang disyaratkan dalam PBI 1991, begitu juga untuk kricak batu pecah batu kapur.

- Bahan agregat kasar batu pecah dari batu kapur untuk pembuatan beton yaitu cukup baik untuk pembuatan beton dengan mutu K. 175 dan termasuk beton klas II.

- Dari hasil penelitian kekuatan tekan karakteristiknya adalah $\sigma^{1} \mathrm{bk}=215,41$ $\mathrm{kg} / \mathrm{cm}^{2}$. Berarti beton dengan campuran : 1 PC Gresik : 2 pasir : 3 kricak ini dapat digunakan untuk pembuatan konstruksi rumah tinggal.

\section{Saran}

Dari hasil penelitian ini kiranya peneliti menyarankan bahan - bahan alternatif untuk pembuatan konstruksi perumahan yang murah dapat lebih ditingkatkan pada masa - masa mendatang, karena kita mencari bahan bangunan yang murah tetapi memenuhi syarat kwalitas bahan yang baik. Dan akhirnya dapat menekan biaya pembuatan rumah, terutama untuk rumah sederhana.

\section{DAFTAR PUSTAKA.}

1. Ahmad Antono, 1989, Beton Tulangan , Andi Offset, Yogyakarta.

2. Dewan Normalisasi Indonesia, 1991, Peraturan Beton Bertulang Indonesia, 1991, Jakarta.

3. Darsono 1986, Konstruksi Beton Metode Plastis, Cipta Offset, Jakarta.

4. Lembaga Penyelidikan Masalah Bangunan, 1990, Peraturan Umum Bahan Bangunan Indonesia, Bandung. 
5. Trimulyono, 2005, Teknologi Beton, Andi Offset, Yogyakarta

6. Paul Nugraha dan Antoni, 2007, Teknologi

Beton, Andi Offset, Yogyakarta. 